\title{
STAN OBECNY SEKTORA ENERGETYKI SLONECZNEJ W POLSCE I PROGNOZA JEJ WYKORZYSTANIA W PRZYSZLOŚCI
}

\begin{abstract}
W artykule przedstawiono ogólne pojęcia związane ze stanem sektora energetyki słonecznej w Polsce oraz z finansowaniem i pomocą publiczną programów wykorzystania kolektorów słonecznych. Dokonano porównania polskiego sektora energetyki słonecznej z innymi krajami UE i prognozy wykorzystania energii słonecznej w przyszłości.
\end{abstract}

Słowa kluczowe: kolektory słoneczne, finansowanie, pomoc publiczna

\section{Wprowadzenie}

Rozwój cywilizacji jest powiązany ze wzrostem zużycia energii przez człowieka. W 1995 roku zapotrzebowanie na energię bezpośrednią w Polsce wynosiło $98,9 \mathrm{ml}$ t.p.u, w 2000 - 102,4 ml t.p.u, a w 2010 - $109 \mathrm{ml}$ t.p.u. [1]. Ta rosnąca tendencja, wzrost liczby ludności na świecie, malejące zasoby konwencjonalnych źródeł energii, ogromny wzrost zanieczyszczenia środowiska, zwłaszcza stężenia dwutlenku węgla w atmosferze, oraz coraz większy nacisk na ochronę środowiska spowodowały, że nieodnawialne zasoby energetyczne zastępuje się odnawialnymi.

Do odnawialnych nieorganicznych źródeł energii można zaliczyć wiatr, geotermię, wody lądowe, morza i oceany, pływy i fale, różnicę temperatury warstw wody oraz promieniowanie słoneczne, z którym są wiązane największe nadzieje. To właśnie energetyka słoneczna cieplna jest jednym z najszybciej rozwijających się sektorów energetyki odnawialnej w Polsce. Średnie roczne tempo wzrostu w latach 2001-2010 wynosiło ponad 47\%.

Centrum Badania Opinii Społecznej (CBOS) w 2009 r. wykazało, że w Polsce energia słoneczna jest uznawana za najbardziej przyjazną dla środowiska i klimatu. Społeczna akceptacja i obiecujące technologie wykorzystujące energię Słońca sprawiły, że sektor energetyki słonecznej jest na najlepszej drodze, aby w znacznym stopniu wesprzeć realizację dyrektywy UE o promocji 
stosowania odnawialnych źródeł energii, której celem jest 15\% udział energii ze źródeł odnawialnych w bilansie zużycia energii w 2020 r.

\section{Nasłonecznienie obszaru Polski}

\subsection{Klasyfikacja nasłonecznienia obszaru Polski}

Na terenie Polski nasłonecznienie zasadniczo nie różni się od występującego w pozostałych krajach Europy Środkowej. Ilość energii słonecznej w zależności od regionu mieści się $\mathrm{w}$ przedziale od 950 do $1250 \mathrm{~W} / \mathrm{m}^{2}$, co daje zysk energetyczny z $1 \mathrm{~m}^{2}$ powierzchni kolektora w granicach od 500 do $700 \mathrm{~kW}$ energii cieplnej rocznie. Instalowanie kolektorów słonecznych na obszarze Polski pozwala zaoszczędzić minimum $50 \%$ rocznego zapotrzebowania na energię cieplną do celów ciepłej wody użytkowej.

Warunki meteorologiczne w Polsce charakteryzują się nierównomiernym rozkładem promieniowania w cyklu rocznym. Na sześć miesięcy sezonu wiosenno-letniego przypada około $80 \%$ całkowitej rocznej sumy nasłonecznienia. Czas aktywności Słońca wynosi 16 h, w zimie zaś zaledwie 8. Roczna średnia wartość sum nasłonecznienia w Polsce to $1600 \mathrm{~h}$.

Roczne sumy całkowitego promieniowania padającego na obszarze Polski dziela jej terytorium na cztery regiony:

1) pas nadmorski, ograniczony izolinią $950 \mathrm{kWh} / \mathrm{m}^{2} \cdot$ rok - Kołobrzeg,

2) wschodnia część Polski, ograniczona izolinią $950 \mathrm{kWh} / \mathrm{m}^{2} \cdot$ rok - Zamość,

3) pozostała część Polski od południa, ograniczona izolinią $900 \mathrm{kWh} / \mathrm{m}^{2} \cdot$ rok - Warszawa,

4) południowa część Polski, ograniczona od północy izolinią 900 $\mathrm{kWh} / \mathrm{m}^{2} \cdot$ rok - Zakopane.

W województwie podkarpackim średnie nasłonecznienie miesięczne w ostatnich dziesięciu latach wynosiło w grudniu $0,8 \mathrm{kWh} / \mathrm{m}^{2} \cdot$ doba, natomiast w lipcu $-6,04 \mathrm{kWh} / \mathrm{m}^{2}$ - doba.

W kolektorach cieplnych i słonecznych modułach fotowoltanicznych istotne znaczenie dla celów energetycznych, oprócz nasłonecznienia, ma także średnia i miesięczna temperatura powietrza. Dla obszaru Polski charakterystyczne jest przesunięcie maksimum temperatury powietrza przypadającego na lipiec, względem występującego w czerwcu maksymalnego nasłonecznienia [2]. Nasłonecznienie obszaru Polski jest ściśle powiązane z porą roku, a więc też z długością dnia. Średnią długość dnia w zależności od miesiąca przedstawia rys. 1.

\subsection{Kąt padania promieni}

Aby wykorzystać energię słoneczną do celów grzewczych oraz do otrzymywania energii elektrycznej, należy uwzględnić kąt padania promieni. Ko- 
nieczne jest więc odpowiednie usytuowanie układu absorbującego względem stron świata oraz umieszczenie go pod kątem nachylenia do poziomu. Kąt nachylenia powinien być optymalny dla położenia kolektora. W przypadku pół-

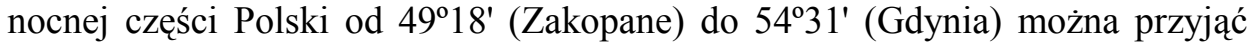
średnią szerokość $52^{\circ}$, dla której optymalny kąt nachylenia $\alpha$ powinien być zgodny $\mathrm{z}$ danymi zamieszczonymi $\mathrm{w}$ tab. 1 . Płaszczyznę wystawioną na działanie promieniowania słonecznego należy ustawić w stosunku do pozornego ruchu Słońca, tak aby promienie padały na nią prostopadle. W praktyce układ sterowany mechanicznie jest rzadko wykorzystywany, natomiast powszechnie są stosowane okresowe zmiany kąta nachylenia płaszczyzny do poziomu [3].

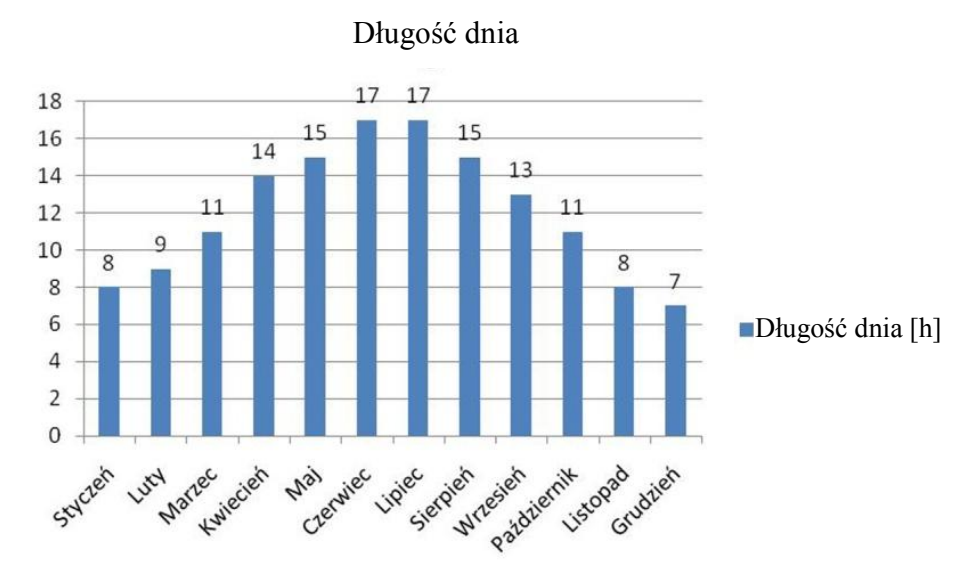

Rys. 1. Długość dnia w Polsce

Tabela 1. Optymalne nachylenie płaskiej powierzchni absorbującej promieniowanie słoneczne względem płaszczyzny poziomej dla szerokości geograficznej $52^{\circ} \mathrm{N}$ w poszczególnych miesiącach roku w przypadku ekspozycji południowej

\begin{tabular}{|l|c|c|c|c|c|c|c|c|c|c|c|c|}
\hline Miesiąc roku & I & II & III & IV & V & VI & VII & VIII & IX & X & XI & XII \\
\hline Kąt nachylenia $\alpha\left[^{\circ}\right]$ & 78 & 70 & 50 & 48 & 39 & 35 & 36 & 44 & 54 & 64 & 76 & 79 \\
\hline
\end{tabular}

W przypadku montażu kolektorów skierowanych na południe bez możliwości zmieniania nachylenia płaszczyzny najkorzystniejszym kątem nachylenia płaszczyzny dla okresu ciepłego jest $\alpha=42,5^{\circ}$, natomiast dla okresu chłodnego $\alpha=70^{\circ}$. 


\section{Stan obecny sektora energetyki słonecznej w Polsce}

\subsection{Finansowanie i pomoc publiczna}

Na sprzedaż kolektorów słonecznych w Polsce ma wpływ możliwość dofinansowania ze środków publicznych. W ostatnich latach głównym źródłem dofinansowania sektora energetyki słonecznej była Fundacja EkoFundusz, która w 2012 r. ma zakończyć swoją działalność. Fundacja wspierała rozwój budowy instalacji solarnych, realizując program „szybkiej ścieżki”, pozwalający na otrzymanie dofinansowania na budowę instalacji o wielkości powyżej $50 \mathrm{~m}^{2}$, stanowiącego do $40 \%$ kosztów. W latach 2010-2011 prawie 50 instalacji słonecznych zostało sfinansowane przez fundację. Ich wartość na 2010 r. wynosiła 44 mln zł. W latach 1997-2007 średnia roczna wartość dotacji wynosiła 2,4 mln zł. Dzięki wsparciu fundacji zainstalowano kolektory o całkowitej powierzchni czynnej wynoszącej 18,5 tys. $\mathrm{m}^{2}$.

Jednostkom samorządu terytorialnego i stowarzyszeniom dotacji udziela także Fundusz Ochrony Środowiska i Gospodarki Wodnej. W ostatnich latach dotacje na zakup instalacji słonecznych wyniosły $25,5 \mathrm{mln}$ zł, natomiast łączny koszt inwestycji ponad $221 \mathrm{mln}$ zł. Zakończenie inwestycji jest planowane na $2012 \mathrm{r}$.

Najtrudniej jest uzyskać wsparcie na zakup instalacji słonecznych właścicielom domów jednorodzinnych. Inwestycje tego typu wspiera Program Ograniczenia Niskiej Emisji (PONE). Inwestycja jest realizowana $w$ formie dotacji wypłacanej przez urząd gminy.

W latach 2005-2008 średnioroczne wsparcie dla energetyki słonecznej bez środków UE wynosiło ok. $24 \mathrm{mln}$ zł na rok. Obecnie możliwe jest uzyskanie dotacji z funduszy UE z Regionalnego Programu Operacyjnego (RPO). Największe dofinansowania w ramach RPO uzyskały województwa mazowieckie, małopolskie, podkarpackie i lubelskie. Oszacowane całkowite dofinansowanie inwestycji w energetyce słonecznej do $2013 \mathrm{r}$. wynosi $280 \mathrm{mln}$ zł, co daje ok. 56 mln zł na rok, które będzie dostępne głównie z krajowych funduszy ochrony środowiska [3].

\subsection{Porównanie polskiego sektora energetyki słonecznej z innymi krajami UE}

W ostatnich latach w całej Europie dynamicznie wzrosła sprzedaż kolektorów słonecznych. Liderami w tej dziedzinie są Niemcy, Hiszpania, Włochy, Francja, Austria i Grecja. Porównanie systemów wsparcia w wybranych państwach UE przedstawia tab. 2. [3].

Najskuteczniejszymi metodami wsparcia są dotacje do zakupu instalacji słonecznych. Korzystne są również ulgi podatkowe oraz tzw. „obowiązek słoneczny". W krajach o najwyższym bilansie sprzedaży kolektorów słonecznych 
dotacje systemów w budynkach jednorodzinnych sięgają od 7 do 37\% kosztów. Biorąc pod uwage „obowiązek słoneczny”, można stwierdzić, że najbardziej rozwiniętym krajem jest Hiszpania, w której rząd federalny wprowadził obowiązek stosowania systemów solarnych do przygotowania ciepłej wody użytkowej. Polski rynek charakteryzuje jeden z największych wzrostów sprzedaży, jednak nie posiada spójnego systemu.

Tabela 2. Zestawienie wsparcia zakupu instalacji słonecznych w krajach UE

\begin{tabular}{|c|c|c|c|}
\hline Kraj & $\begin{array}{c}\text { Dotacje [\%] do kosztów } \\
\text { budowy instalacji } \\
\text { slonecznych dla } \\
\text { właścicieli domków } \\
\text { jednorodzinnych }\end{array}$ & $\begin{array}{c}\text { Ulgi podatkowe/kredyty } \\
\text { podatkowe }\end{array}$ & $\begin{array}{c}\text { Obowiązek } \\
\text { minimalnego udziału } \\
\text { energii słonecznej } \\
\text { w pokryciu zapotrze- } \\
\text { bowania na c.w.u. }\end{array}$ \\
\hline Niemcy & $\begin{array}{c}7-8 \% \text { w przypadku c.w.u., } \\
8-11 \% \text { w przypadku syste- } \\
\text { mów dwufunkcyjnych }\end{array}$ & - & $15 \%$ \\
\hline Włochy & - & $\begin{array}{c}\text { odliczenie podatku dochodo- } \\
\text { wego w wysokości 55\%, } \\
\text { maks. 60 tys. } € \text { przez 5 lat }\end{array}$ & $50 \%$ \\
\hline Hiszpania & $37 \%$ & - & $30-70 \%$ \\
\hline Francja & $15-20 \%$ & $\begin{array}{c}\text { kredyt podatkowy do 50\% } \\
\text { kosztów instalacji }\end{array}$ & - \\
\hline Austria & do $35 \%$ & $\begin{array}{c}\text { odliczenia od podatku docho- } \\
\text { dowego do kwoty } 3 \text { tys. } €\end{array}$ & $25 \%$ \\
\hline Grecja & - & $\begin{array}{c}\text { odliczenia od podatku docho- } \\
\text { dowego w wysokości } 20 \% \\
\text { kosztów zakupu instalacji }\end{array}$ & - \\
\hline Polska & niespójny system & - & - \\
\hline
\end{tabular}

\section{Prognoza wykorzystania energii słonecznej do 2020 r.}

\subsection{Wprowadzenie do prognozy}

Rozwój energetyki słonecznej w latach poprzednich nie był przedmiotem analiz. Najważniejszym dokumentem w sprawie energetyki odnawialnej jest „Strategia rozwoju energetyki odnawialnej”, opublikowana przez Ministerstwo Środowiska w 2000 r. i zatwierdzona uchwałą sejmu w 2001. Jest to pierwszy dokument wyznaczający ilościowy cel rozwoju energii odnawialnej do 2010 $(7,5 \%)$ i 2020 r. $(14 \%)$.

Aby potwierdzić założenia „Strategii rozwoju energetyki odnawialnej” i przygotować programy rozwoju, zostały wykonane symulacje. Wyniki tej symulacji pokazały, że udział energii słonecznej w całościowym udziale energii ze źródeł odnawialnych wynosił 0,7\% w 2010 r., a w 2020 osiagnie 1,7\% [3]. 


\subsection{Założenia do prognozy}

Według danych Eurostatu ciepło pochodzące zarówno z systemów ciepłowniczych, jak i z bezpośredniego zużycia paliw w 2005 r. stanowiło $77 \%$ całkowitego zużycia energii w Polsce. Sektor usług i mieszkalnictwa zużywa 2/3 ciepła i jest równocześnie sektorem o największych możliwościach zwiększenia efektywności zużycia energii oraz wykorzystania odnawialnych źródeł.

Prognoza zakłada, że [3]:

- udział energii odnawialnej powinien być zrealizowany z nadwyżką wynikająca z pominięcia biopaliw i biomasy wyeksportowanych poza granicę Polski i z konieczności uwzględnienia marginesu bezpieczeństwa,

- w produkcji ciepła ze źródeł odnawialnych ważną rolę odegrają kolektory słoneczne, co będzie stanowić $10 \%$ całkowitej produkcji,

- w 2050 r. udział odnawialnych źródeł energii wzrośnie do 50\%,

- zużycie paliw kopalnianych spadnie o $60 \%$, a węgiel zostanie wyeliminowany przez zwiększenie zużycia gazu.

\subsection{Scenariusz rozwoju energetyki słonecznej do 2020 r.}

Rozwój energetyki słonecznej jest związany $\mathrm{z}$ modelem demand site - z konkretnymi potrzebami. Najważniejsze potrzeby grzewcze w Polsce stanowią:

- ciepła woda użytkowa (c.w.u.) w mieszkalnictwie,

- c.w.u. w usługach i sektorze publicznym,

- centralne ogrzewanie (c.o.) w mieszkalnictwie,

- c.o. w usługach i sektorze publicznym,

- słoneczne chłodzenie w mieszkalnictwie,

- słoneczne chłodzenie w sektorze usług,

- ciepło technologiczne w przemyśle i rolnictwie.

Wszystkie te potrzeby moga być realizowane indywidualnie lub w systemie zbiorowego zaopatrzenia w ciepło i chłód.

W części ciepłowniach zlokalizowanych w pobliżu wód geotermalnych będzie możliwe zastosowanie energii geotermalnej, w innych - biomasy, jednak cena jej zakupu może być za wysoka dla niektórych ciepłowni. Przyczyni się to do wyboru przez część ciepłowni energii słonecznej do wstępnego podgrzewania czynnika w sieciach ciepłowniczych, a zwłaszcza do pokrycia zapotrzebowania na c.w.u. w okresie letnim. Rosnący potencjał rynkowy energii słonecznej można postrzegać w kontekście wzrostu cen paliw kopalnianych, a także zwiększenia standardów komfortu cieplnego w biurach, gdzie chłód może być pozyskiwany z wykorzystaniem energii słonecznej.

Do zwiększenia udziału energii słonecznej może się przyczynić dyrektywa UE o promocji stosowania odnawialnych źródeł energii, która ma spowodować wzrost zainteresowania słonecznym ogrzewaniem pomieszczeń mieszkalnych 
i biurowych. Wraz z rozwojem budownictwa coraz częściej będą stosowane słoneczne systemy ogrzewania mieszkań, klimatyzacji i słonecznego chłodzenia. Efekty zjawisk sprzyjających rozwojowi energetyki słonecznej będą szczególnie widoczne po $2020 \mathrm{r}$.

Symulacje wykazały, że po 2010 r. wykorzystywanie energii do lokalnego przygotowania c.w.u. będzie wspierane dotacjami. Po 2015 roku duże znaczenie na rynku będą miały dwufunkcyjne systemy w mieszkalnictwie jednorodzinnym (ogrzewanie słoneczne wraz z przygotowaniem c.w.u.). Do 2020 roku na rynku mają pojawić się także systemy słonecznego chłodzenia. Szybki rozwój zapotrzebowania na ciepło i chłód pozyskiwane za pomoca instalacji słonecznych spowoduje gwałtowny rozwój rynku oraz zwiększenie zdolności produkcyjnych.

Średnioroczne tempo wzrostu sektora energetyki słonecznej w latach 2005-2030 wyniesie 26\%, przy czym w 2011-2015 będzie stanowić 45\%, w 2016-2020 - 26\%, 2026-2030 - 7\%. W symulacji uwzględniono spowolnienie wzrostu w latach 2013-2014 spowodowane wyczerpaniem środków UE. Powierzchnia instalowanych kolektorów w Polsce w 2022 r. zbliży się do stanu nasycenia [3].

\subsection{Korzyści dla gospodarki i mieszkańców}

Wykorzystanie energii promieniowania słonecznego nie tylko obniża koszty, ale też daje wiele korzyści mieszkańcom i gospodarce. Niepodważalną zaletą kolektorów słonecznych jest ich korzystny wpływ na środowisko naturalne w wyniku redukcji emisji zanieczyszczeń i gazów cieplarnianych do atmosfery. Energetyka słoneczna termiczna jest jedną $z$ najczystszych i efektywnych ekonomicznie technologii energetycznych. Następstwem rozwoju sektora energetyki słonecznej jest redukcja kosztów środowiskowych, jakie musiałyby być poniesione podczas wykorzystania konwencjonalnych systemów grzewczych. W realizacji założonego wcześniej scenariusza będzie możliwa redukcja emisji $\mathrm{CO}_{2}$ do atmosfery.

Osiagnnięcie $68 \%$ redukcji będzie możliwe w wyniku zainstalowania kolektorów słonecznych na cele c.w.u w mieszkalnictwie, 12\% systemów c.w.u. w usługach i sektorze publicznym, a 7\% systemów c.o. w mieszkalnictwie. Ta skala redukcji ma stosunkowo niewielki wpływ na wypełnienie do 2020 r. dyrektywy o handlu emisjami. Przewidywany udział sektora energetyki słonecznej $\mathrm{w}$ redukcji emisji $\mathrm{CO}_{2}$ to jedynie $10 \%$. Sektor energetyki słonecznej w porównaniu z innymi technologiami cechuje się wysoką wydajnością energetyczną z jednostki powierzchni i 30-50-krotnie większą sprawnością przetworzenia w ciepło energii słonecznej w stosunku do ciepła z biomasy.

Analizując koszty produkcji ciepła, można wnioskować, że prognozowany rozwój energetyki słonecznej przyniesie znaczące korzyści makroekonomiczne oraz zapewni bezpieczeństwo w aspekcie klimatyczno-energetycznym. W przypadku instalacji słonecznych całkowite koszty produkcji ciepła są ujęte głównie 
w nakładach inwestycyjnych. Odmienna sytuacja występuje w przypadku pozostałych technologii grzewczych, gdyż znaczący udział całkowitych kosztów produkcji ciepła stanowią koszty zakupu paliwa i energii potrzebnej do pracy urządzeń. Rozwój energetyki słonecznej jest zatem działaniem perspektywicznym, redukującym obecne i przyszłe wydatki ponoszone na cele grzewcze.

Rozwój sektora energetyki słonecznej ma niezwykle ważny wpływ na rynek pracy. Obecnie na terenie całej Europy zapewnia powstanie w ciągu roku ponad 40000 stanowisk pracy (co w przeliczeniu na moc kolektorów słonecznych daje jedno pełnoetatowe stanowisko na $80 \mathrm{~kW}$ mocy kolektorów). Należy zaznaczyć, że połowa miejsc w tym sektorze to pracownicy zajmujący się sprzedażą detaliczną, instalacją kolektorów i serwisem poinstalacyjnym, co zapewnia miejsca pracy o charakterze lokalnym (w małych i średnich firmach). Według prognoz Europejskiej Rady Energetyki Odnawialnej w 2020 r. zatrudnienie w sektorze energetyki słonecznej wzrośnie do 660000 miejsc pracy [3].

\subsection{Strategia wsparcia dla energetyki słonecznej}

Nowe przemysły pojawiające się na rynku spotykają się z problemem „błędnego koła”. Przekładając to na pojawienie się i rozwój energetyki słonecznej w Polsce, można stwierdzić, że znacznie więcej osób zainstalowałoby systemy słoneczne do podgrzewania wody, gdyby były tańsze, a jednocześnie systemy te nie będą tańsze dopóki popyt na nie nie wzrośnie. Problem ten jest najczęściej rozwiązywany przez takie działania, jak dotacje, ulgi podatkowe, działanie na rzecz poprawy efektywności i spadku kosztów. W Polsce sektor energetyki słonecznej poszerza swoją działalność w sposób zrównoważony, głównie dzięki działaniom firm produkcyjnych i stosunkowo niewielkim, ale ważnym wsparciu funduszy ekologicznych. Mimo wielu barier ekonomicznych, jest to odpowiedni czas dla energicznego rozwoju tego sektora. Rosnąca skala produkcji spowoduje spadek kosztów. W latach 2005-2008 na budowę nowych instalacji solarnych przeznaczono ok. $24 \mathrm{mln}$ zł rocznie ze środków publicznych, co daje energetyce słonecznej pierwsze miejsce w energetyce odnawialnej. W żadnym innym sektorze nie zyskano tak dużo przy niewielkim wkładzie publicznym.

Zbilansowane środki publiczne na lata 2011-2015 przeznaczone na energetykę słoneczną wyniosą $50 \mathrm{mln}$ zł rocznie, a zapotrzebowanie na kolektory będzie wyższe niż w latach ubiegłych. Zakładając spadek cen zakupu systemów słonecznych z $3000 \mathrm{z} / \mathrm{m}^{2}$ do $2500 \mathrm{z} / \mathrm{m}^{2}$, skala inwestycji wzrośnie do ok. 2,5 mld zł rocznie. Aby utrzymać średnie wsparcie ze środków publicznych na poziomie $12 \%$, niezbędna jest roczna kwota dofinansowania równa $180 \mathrm{mln}$ zł. Kwota ta będzie wyzwaniem dla funduszy ekologicznych, funduszy UE, a także budżetu państwa. Aby sprostać tym wymaganiom, konieczne jest podjęcie następujących działań: 
- poszerzenie kręgu beneficjentów, zwłaszcza na szczeblu regionalnym, o klientów indywidualnych oraz uproszczenie systemu dotacji,

- stworzenie powszechnego wsparcia dla inwestorów indywidualnych w postaci ulg podatkowych,

- zwolnienie od podatku VAT materiałów, z których są wykonywane instalacje słoneczne,

- stworzenie systemu promocji certyfikowanych urządzeń opartych na europejskich normach lub zgodnych z krajowymi przepisami,

- promocja eksportu systemów słonecznych do krajów UE,

- wsparcie funduszy ekologicznych i rządu umożliwiające uzyskanie certyfikatów jakości, stworzenie rządowej kampanii edukacyjno-informacyjnej, zwłaszcza wśród właścicieli domów mieszkalnych, obiektów turystycznych i szkół.

\section{Podsumowanie}

Podsumowując, można stwierdzić, że na rozwój sektora energetyki słonecznej ma wpływ jej dofinansowanie. Obecnie w Polsce najłatwiej uzyskać dofinansowanie na budowę dużych instalacji słonecznych. Aby zwiększyć wykorzystanie energii słonecznej, należy stworzyć spójny system umożliwiający dotacje na małe instalacje, pokrywające zapotrzebowanie ciepła na cele ciepłej wody użytkowej i centralnego ogrzewania.

Sektor energetyki słonecznej, w porównaniu z innymi technologiami, cechuje się wysoką wydajnością energetyczną z jednostki powierzchni. Jego zaletami są: brak konieczności dostarczania paliwa, ograniczenie emisji spalin i gazów cieplarnianych do atmosfery oraz praktycznie bezpłatne eksploatowanie. Koszty ponoszone w sektorze energetyki słonecznej są związane głównie z zakupem i montażem kolektorów, co czyni promieniowanie słoneczne najbardziej perspektywicznym źródłem energii.

\section{Literatura}

[1] Gronowicz J.: Niekonwencjonalne źródła energii. Wydawnictwo Instytutu Technologii Eksploatacji - PIB, Radom-Poznań 2008.

[2] Klugmann-Radziemska E., Klugmann E.: Systemy słonecznego ogrzewania i zasilania elektrycznego budynków. Wydawnictwo Ekonomia i Środowisko, Białystok 2002.

[3] Instytut Energetyki Odnawialnej. Wizja rozwoju energetyki słonecznej termicznej w Polsce wraz z planem działań do 2020 r., Warszawa 2009. 


\section{CONDITIONS OF SOLAR POWER AREA IN POLAND} AND PREDICTION OF ITS FUTURE USAGE

S u m m a r y

The paper represents general terms relating to conditions of solar power area in Poland, financing and public support for using solar collectors in the country. It's been compared the Polish solar power area with the other Europe Union countries, and also considered prediction of future using solar power.

Keywords: solar collectors, financing, public support

DOI:10.7862/rb.2012.5 